\title{
PHLOEM MOBILITY OF BORON IN TWO EUCALYPT CLONES ${ }^{(1)}$
}

\author{
Edson Marcio Mattiello(2), Hugo Alberto Ruiz ${ }^{(3)}$, Ivo Ribeiro da Silva ${ }^{(3)}$, \\ Jorge Eduardo Souza Sarkis ${ }^{(4)}$, Júlio César Lima Neves ${ }^{(3)} \&$ Murilo \\ Marques Pucci ${ }^{(5)}$
}

\begin{abstract}
SUMMARY
Boron deficiency causes large productivity losses in eucalypt stands in extensive areas of the Brazilian Cerrado region, thus understanding $B$ mobility is a key step in selecting genetic materials that will better withstand B limitation. Thus, in this study B mobility was evaluated in two eucalypt clones (68 and 129), under B sufficiency or B deficiency, after foliar application of the ${ }^{10} \mathrm{~B}$ isotope tracer to a single mature leaf. Samples of young tissue, mature leaves and roots were collected $0,1,5,12$ and 17 days after ${ }^{10} \mathrm{~B}$ application. The ${ }^{10} \mathrm{~B}:{ }^{11} \mathrm{~B}$ isotope ratio was determined by HR-ICP-MS. Samples of leaves and xylem sap were collected for the determination of soluble sugars and polyalcohols by ion chromatography. Boron was translocated within eucalypt. Translocation of foliar-applied ${ }^{10} \mathrm{~B}$ to the young tissues, mature leaves and roots was higher in clone 129 than in 68 . Seventeen days after ${ }^{10} \mathrm{~B}$ application to a single mature leaf, between 14 and $18 \%$ of $B$ in the young tissue was originated from foliar $B$ application. In plants with adequate $B$ supply the element was not translocated out of the labeled leaf.
\end{abstract}

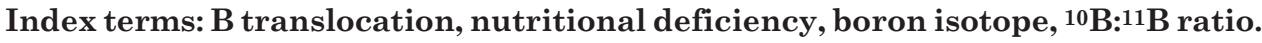

\footnotetext{
(1) Parte da Tese de Doutorado do primeiro autor apresentada à Universidade Federal de Viçosa - UFV. Apoio financeiro: CNPq e FAPEMIG. Recebido para publicação em maio de 2009 e aprovado em outubro de 2009.

(2) Analista Ambiental - Vale. CEP 68633-000 Dom Eliseu (PA). E-mail: mattielloem@yahoo.com.br

(3) Professor do Departamento de Solos da Universidade Federal de Viçosa - UFV. CEP 36570-000 Viçosa (MG). E-mails: hruiz@ufv.br; ivosilva@ufv.br; julio.neves@pq.cnpq.br

(4) Pesquisador do Instituto de Pesquisas Energéticas e Nucleares - IPEN-CNEN/SP. CEP 055508-000 São Paulo (SP). E-mail: jesarkis@ipen.br

(5) Discente de Agronomia, UFV. E-mail: murilo_pucci@yahoo.com.br
} 


\title{
RESUMO: MOBILIDADE FLOEMÁTICA DE BORO EM DOIS CLONES DE EUCALIPTO
}

\begin{abstract}
A deficiência de boro tem causado perdas expressivas de produtividade em extensas áreas de eucalipto no Brasil, principalmente na região do Cerrado. A mobilidade de B é um fator chave na seleção de materiais genéticos mais tolerantes à deficiência deste nutriente. Neste trabalho, a mobilidade de B foi avaliada em dois clones de eucalipto (68 e 129), com e sem deficiência de B, após a aplicação foliar do traçador isotópico ${ }^{10} \mathrm{~B}$ em uma única folha madura. Amostras de tecidos jovens, folhas maduras e raizes foram coletadas nos tempos de 0, 1, 5, 12 e 17 dias após a aplicação. A determinação da razão isotópica ${ }^{10} \mathrm{~B}:{ }^{11} \mathrm{~B}$ foi feita por meio de HR-ICP-MS. Foram coletadas amostras de folhas e do exsudato xilemático para determinação de açúcares solúveis e poliálcoois, por meio de cromatografia iônica. Houve translocação de B no eucalipto. O clone 129 apresentou maior translocação de B da folha aplicada para tecidos jovens, folhas maduras e raízes, quando comparado ao clone 68. Aos dezessete dias após a aplicação do ${ }^{10} \mathrm{~B}$ em uma única folha madura, entre 14 e $18 \%$ do $\mathrm{B}$ do tecido jovem era proveniente do $B$ aplicado. As plantas com suprimento adequado de B não apresentaram translocação do elemento.
\end{abstract}

Termos de indexação: translocação de B, deficiência nutricional, isótopico de B, razão ${ }^{10} B:{ }^{11} B$.

\section{INTRODUCTION}

Boron is the micronutrient that is most frequently deficient (Gupta, 1993b). In Brazil, soils are Bdeficient in several regions, especially in the Cerrado region, where eucalypt cultivation has expanded in recent decades. Boron deficiency is one of the most limiting factors for eucalypt growth, causing malfunctioning mainly of younger plant tissues (Sgarbi et al., 1999). A characteristic symptom of B deficiency is the death of the apical meristem, known as dieback, resulting in lateral oversprouting. Bdeficient plants usually present losses in wood yield and the wood quality is reduced. Besides, lateral sprouting difficult mechanized stem harvest.

There have been indications that eucalypt clones respond distinctly to $\mathrm{B}$ deficiency under field conditions. These differences are possibly associated to the specific nutritional efficiency for the element. A greater nutritional efficiency can be due to different mechanisms: greater ability to uptake $\mathrm{B}$ from the soil or growth medium, the forms of nutrient taken up, and its distribution in the plant and/or the ability to make efficient use of the element (Rerkasem \& Jamjod, 1997). An efficient $B$ remobilization can enhance the adaptability of certain genotypes to cultivation areas where $\mathrm{B}$ deficiency is common.

For several years B was considered a low-mobility nutrient in the plant phloem (Oertli \& Richardson, 1970; Raven, 1980). In agreement with this concept, $B$ accumulates more in mature leaves and $B$ deficiency symptoms are first expressed in young tissues. It takes a few hours until deficiency symptoms can be noticed in the root apex and only minutes until they are evidenced in the pollen tube (Gupta, 1993; Dell \&
Huang, 1997). The low B mobility has been attributed to the low solubility of organic compounds in the phloem sap and to the B fixation in cell components of older leaves (Hu \& Brown, 1994; Shelp et al., 1995). However, a number of studies have shown that B can be more mobile in some plant species (Pichioni et al., 1995; Brown \& Hu, 1996; Brown \& Shelp, 1997; Konsaeng at al., 2005), resulting in the differentiation of plant groups with high and low B mobility (Brown $\&$ Shelp, 1997). The difference between these two groups can be related to the presence of low molecular mass photosynthates, such as sugars and polyalcohols. These compounds form complexes with B, facilitating B transport into the phloem. Boron mobility in plants of the genera Malus, Prunus and Pyrus was related to the presence of sorbitol as main photosynthate (Brown \& Hu, 1996). Complexes of B-sorbitol, Bmanitol and also B-fructose (Hu et al., 1997) and Bmalic acid (Dembitsky et al., 2002) have been found in the phloem sap of plants with higher B mobility.

Boron mobility in the phloem was confirmed in trials in which the ${ }^{10} \mathrm{~B}$ isotope was applied to mature apple and pear leaves. Approximately $50 \%$ of the B absorbed by the leaf was translocated within six hours after application and could be detected in the phloem sap of these plants (Picchioni et al., 1995). In olive trees, ${ }^{10} \mathrm{~B}$ applied to mature leaves was translocated to the new parts, inflorescence and fruits. With the foliar application of the nutrient, the glucose concentration was reduced and manitol concentration increased in the leaf petiole. This suggests that a Bmanitol complex regulates $B$ mobility in the phloem (Delgado et al., 1994). However, an increase of ${ }^{10} \mathrm{~B}$ was observed in young leaves and roots of conifers after its application to mature leaves in species with high contents as well as in those with rather low 
sorbitol and manitol contents (Lehto et al., 2000, 2004). Moreover, no ${ }^{10} \mathrm{~B}$ translocation was observed in some species, despite their high polyalcohol contents. These results evidenced that other mechanisms and/or organic compounds may be involved in remobilization of $\mathrm{B}$ in these species.

Boron mobility influences the nutritional diagnosis depending on the application form and date. The sampling of plant tissue to establish a nutritional diagnosis and critical levels is related to B mobility. The sampling of mature leaves may not be adequate for nutritional diagnosis of $\mathrm{B}$ in species with restricted $\mathrm{B}$ mobility since $\mathrm{B}$ concentration in this organ does not reflect the B status in the other growing organs. On the other hand, these leaves can be quite representative in species with B mobility. Also, in species with restricted $\mathrm{B}$ mobility foliar fertilization with B may be little efficient, requiring a continuous supply of the nutrient throughout the growth cycle. On the contrary, plants with greater B mobility can respond more efficiently to the foliar application of the nutrient, which can be applied at longer intervals.

Studies on B mobility in eucalypt are scarce. The higher $\mathrm{B}$ translocation could be a differential response of genotypes, conferring greater tolerance to B deficiency. The knowledge on the magnitude of $\mathrm{B}$ mobility is of fundamental importance for the nutritional management and for the selection of genotypes better adapted to areas where the occurrence of the problem is common.

This study aimed to evaluate the remobilization of foliarly applied-B to other plant organs in two eucalypt clones under deficient or sufficient B supply using the ${ }^{10} \mathrm{~B}$ isotope tracer technique.

\section{MATERIAL AND METHODS}

Forty day-old seedlings of two commercial eucalypt (Eucalyptus grandis x E. urophylla hybrid) were grown during 21 days in a greenhouse in Clark's nutrient solution (Clark, 1975), 1/2 strength, with $10 \mu \mathrm{mol} \mathrm{L}{ }^{-1} \mathrm{~B}$ (natural abundance- $19.8 \%{ }^{10} \mathrm{~B}$ and $80.2 \%{ }^{11} \mathrm{~B}$ ). The $\mathrm{B}$ source was $\mathrm{H}_{3} \mathrm{BO}_{3}$ (Merck, Darmstadt, Germany). Clones 68 and 129 were selected because they are, respectively, sensitive and more tolerant to B deficiency under field conditions. Thereafter, uniform plants of each clone were selected for the experiment. Two thirds of the selected plants were grown without $\mathrm{B}$, and the other third in the presence of $20 \mu \mathrm{mol} \mathrm{L}-1 \mathrm{~B}$ (natural abundance $19.8 \%$ ${ }^{10} \mathrm{~B}$ and $80.2 \%{ }^{11} \mathrm{~B}$ ). After 45 days in these conditions, B deficiency symptoms were manifested in plants grown without the element. At this point, a single mature leaf of plants grown without $\mathrm{B}$ and another grown with $\mathrm{B}$ were immersed in $\mathrm{H}_{3} \mathrm{BO}_{3}$ solution enriched with 99 atom $\%{ }^{10} \mathrm{~B}$ (Aldrich), at a concentration of $1.64 \mathrm{~g} \mathrm{~L}^{-1}{ }^{10} \mathrm{~B}$ during one minute.
This solution was prepared using ultrapure water. Care was taken not to contaminate other plant parts or the nutrient solution with ${ }^{10} \mathrm{~B}$. Half of the plants grown without $\mathrm{B}$ were not treated with ${ }^{10} \mathrm{~B}$ solution to serve as controls. The trial consisted of three treatments with three replications: B-deficient plants without foliar application of ${ }^{10} \mathrm{~B}(-\mathrm{B})$; B-deficient plants with foliar application of ${ }^{10} \mathrm{~B}\left(-\mathrm{B}+{ }^{10} \mathrm{~B}\right.$ foliar $)$; and plants with adequate $\mathrm{B}$ supply with ${ }^{10} \mathrm{~B}\left(+\mathrm{B}+{ }^{10} \mathrm{~B}\right.$ foliar) foliar application. There were five plants per $30 \mathrm{~L}$ pot.

The plants were constantly aired, and the $\mathrm{pH}$ of the solution adjusted to 5.5 every day. The nutrient solution was replaced weekly in order to maintain concentrations of $\mathrm{B}$ and other nutrients as constant as possible.

Samples of root apices, mature leaves and young tissues (young leaves and shoot meristems) from plants of the three treatments were collected at 0 (just before foliar ${ }^{10} \mathrm{~B}$ application), 1, 5, 12 and 17 days after ${ }^{10} \mathrm{~B}$ foliar application. The leaf to which ${ }^{10} \mathrm{~B}$ was applied was also collected. Based on the ${ }^{10} \mathrm{~B}:{ }^{11} \mathrm{~B}$ isotope ratio, $\mathrm{B}$ translocation from the mature leaf treated with ${ }^{10} \mathrm{~B}$ to other plant parts was determined over the course of time. The tissue samples were dried in a forced draft oven at $65^{\circ} \mathrm{C}$ for $96 \mathrm{~h}$. The samples were ground and approximately $0.2 \mathrm{~g}$ of the material was incinerated at $550^{\circ} \mathrm{C}$ in porcelain crucibles; then the residue was dissolved in $5 \mathrm{~mL}$ nitric acid (Merck, Darmstadt, Germany), prepared with ultrapure water, at a concentration of $1.59 \mathrm{~mol} \mathrm{~L}^{-1}$. The residue was filtered through $0.45 \mu \mathrm{m}$ nylon filters (Whatman) and deep-frozen in plastic microtubes.

The ${ }^{10} \mathrm{~B}:{ }^{11} \mathrm{~B}$ isotope ratio was determined by a High Resolution Inductively Coupled Plasma-Mass Spectrometry (HR-ICP-MS, ELEMENT-Thermo Finnigan, Bremen, Germany) (Table 1). Prior to sample analysis, adequate study conditions were established for measurement (calibration). Isotope standards NIST SRM-951, at a ${ }^{10} \mathrm{~B}:{ }^{11} \mathrm{~B}$ ratio of 0.247 , containing $91.85 \mu \mathrm{g} \mathrm{L}^{-1} \mathrm{~B}$, were prepared from stock standard solution and used in the calibration phase and during the analysis series. The standard concentration was similar to the concentrations expected in the diluted sample extracts analyzed. The stock solution $\left(1.000 \mathrm{mg} \mathrm{L}^{-1} \mathrm{~B}\right)$ was prepared based on isotope standard $\left(\mathrm{H}_{3} \mathrm{BO}_{3}\right)$ certified by the National Institute of Standard and Technology (NIST SRM951) with $19.827 \%{ }^{10} \mathrm{~B}$ and $80.173 \%{ }^{11} \mathrm{~B}$, at a weight precision of $0.01 \mathrm{mg}$. Once the analysis conditions were established, the $\mathrm{B}$ isotope ratio $\left({ }^{10} \mathrm{~B}:{ }^{11} \mathrm{~B}\right)$ was determined in the eucalypt plant samples diluted 10 times with $18.2 \mathrm{M} \Omega \mathrm{cm}^{-1}$ deionized water using an automatic sampler.

Based on tissue $\mathrm{B}$ isotope ratios, the percentage of $\mathrm{B}$ derived from foliar fertilization with $\mathrm{H}_{3}{ }^{10} \mathrm{BO}_{3}$ (\% Bdff) was calculated by the following formula:

Bdff $(\%)=\left[\%^{10} \mathrm{~B}\right.$ in sample $-\%{ }^{10} \mathrm{~B}$ in control $) /$ $\left(\%{ }^{10} \mathrm{~B}_{\mathrm{H} 3 \mathrm{BO} 3}-\%{ }^{10} \mathrm{~B}\right.$ in control)] x 100. 
Table 1. Operation conditions of the HRICP-MS

\begin{tabular}{ll}
\hline Instrument & \multicolumn{1}{c}{$\begin{array}{c}\text { Element } \\
\text { (Thermo Finnigan, Bremen, Germany) }\end{array}$} \\
\hline Sensitivity & $10 \mathrm{ng} \mathrm{g}^{-1}{ }^{115} \mathrm{In}=1 \times 10^{6}$ counts \\
RF power & $1250 \mathrm{~W}$ \\
Nebulizer & Meinhardt glass with water-cooled \\
& spray chamber, Scott type \\
Sample uptake & $0.8 \mathrm{~mL}$ min $^{-1}$ \\
Interface & Ni cones \\
Gas flows $(\mathrm{L} \mathrm{min}-1)$ & Plasma $=14$, auxiliary 1.0, \\
& nebulizer $=0.90$ \\
Resolution m $/ \Delta \mathrm{m}$ & 300 \\
Integration window & $80 \%$ \\
Scans & Eletric, number of scans $=30$ \\
Detector & Ion counting \\
\hline
\end{tabular}

Leaf and xylem sap samples were also collected for the determination of sugars and polyalcohols by liquid chromatography. Leaf samples were collected from the $3^{\text {rd }}$ and $4^{\text {th }}$ pairs from the branch apex and stored at $-80{ }^{\circ} \mathrm{C}$ until analysis. Prior to analysis frozen plant samples were ground in liquid $\mathrm{N}$ and then extracted with $4 \mathrm{~mL} 80 \%$ ethanol (v/v). This material was centrifuged at $1.600 \mathrm{~g}$ for $15 \mathrm{~min}$. The supernatant was removed and the residue extracted two more times in $3 \mathrm{~mL} 80 \%$ ethanol (v/v) and centrifuged again. Thereafter, the supernatants were combined and lyophilized. The lyophilization residue was then reconstituted in $2 \mathrm{~mL}$ ultrapure water and filtered in $0.45 \mu \mathrm{m}$ nylon filter membranes. The leaf extract was diluted 10 times and the xylem sap five times just before analysis straight into automatic sampler vials. A $10 \mu \mathrm{L}$ loop was used to inject the samples into an ion chromatograph (DX-600, Dionex, Sunnyvale, California). The soluble carbohydrates and polyalcohols were separated in an analytical column (CarboPac-10, 30 x $0.4 \mathrm{~cm}$, Dionex) using a $\mathrm{NaOH}$ gradient at a $1.0 \mathrm{~mL} \mathrm{~min}^{-1}$ flow rate. The analytes were detected by pulsed amperometry, using a gold electrode in an electrochemical detector. The peaks corresponding to the sample components were identified based on the time of retention of external standards. The areas under the peaks were integrated by Chromeleon software and used in the quantification of the different carbohydrates.

The experimental results were subjected to analysis of variance. The mean $\mathrm{B}$ isotope ratio and standard errors are presented for each clone considering the time of ${ }^{10} \mathrm{~B}$ application to the mature leaf. The soluble sugars and polyalcohols were compared by the least significant difference (Fisher's protected LSD test) at $5 \%$. The clones were compared by the $\mathrm{F}$ test.

\section{RESULTS AND DISCUSSION}

At the time of ${ }^{10} \mathrm{~B}$ foliar application the root and leaf dry matter of the deficient plants of clone 68 was, on average, 0.28 and $5.9 \mathrm{~g} / \mathrm{plant}$, respectively. For clone 129 they were, respectively, $0.24 \mathrm{~g} / \mathrm{plant}$ and $6.5 \mathrm{~g} /$ plant. No statistically significant $(\mathrm{p}>0.05)$ effect of foliar B application were detected in the dry matter production by the two clones due to B application, probably due to the short experimental period (17 d). The B content of roots, mature leaves and young leaves of the deficient plants of clone 68 were 16.54, 2.07 and $6.01 \mathrm{mg} \mathrm{kg}^{-1}$, respectively, versus 78.32, 50.49 and $42.22 \mathrm{mg} \mathrm{kg}^{-1}$ in plants with adequate B supply. The $\mathrm{B}$ content of roots, mature leaves and young leaves of the deficient plants of clone 129 were $22.18,3.08$ and $3.1 \mathrm{mg} \mathrm{kg}^{-1}$, respectively, and $45.71,44.68$ and $36.45 \mathrm{mg} \mathrm{kg}^{-1}$ in plants with adequate B supply. As a result of $\mathrm{B}$ deprivation, typical shoot deficiency symptoms were evident (Figure 1a).

B-deficient plants resumed growth after foliar application of ${ }^{10} \mathrm{~B}$ (Figure $1 \mathrm{~b}$ ). Intense lateral sprouting was observed, mainly close to the leaf treated

(a)

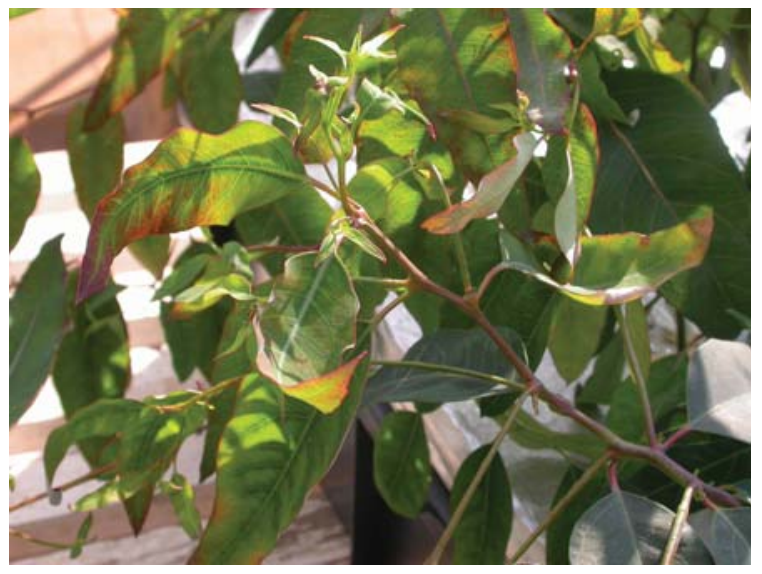

(b)

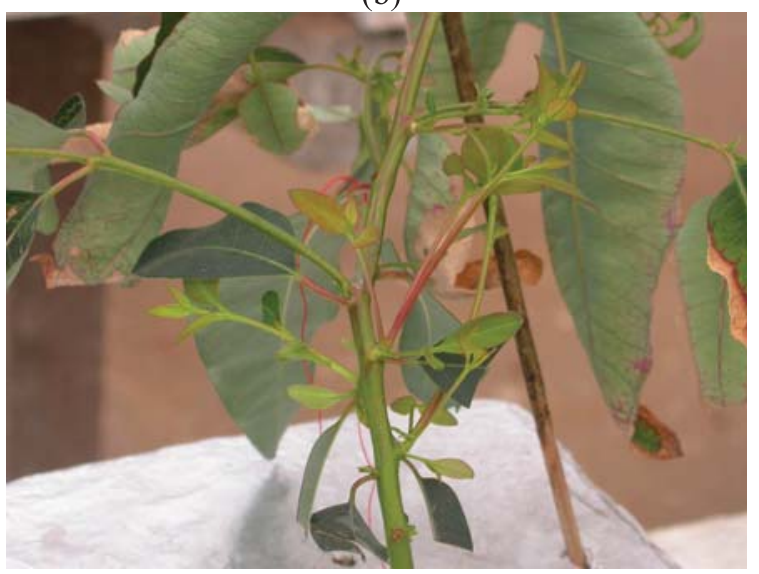

Figure 1. Boron deficient eucalypt plant (a) and emission of lateral sprouts 17 days after ${ }^{10} \mathrm{~B}$ application to a single mature leaf of the Bdeficient plant (b). 
with B, unlike plants with normal B contents. This situation is similar to field observations of shoot meristem dieback caused by B deficiency, followed by lateral oversprouting in later stages when B is no longer limiting. The death of the branch meristem or even the functional disturbance results in the loss of the apical dominance. The production of the hormone auxin, responsible for cell elongation and stem growth, is reduced. The lateral buds, inhibited by auxin, are then stimulated by the hormone cytokinin, responsible for cell division and the development of lateral buds (Wang et al., 2006). Lateral sprouting occurs in an effort to resume growth.

The translocation of ${ }^{10} \mathrm{~B}$ applied to the mature leaf to other plant parts was confirmed by alterations in the ${ }^{10} \mathrm{~B}:{ }^{11} \mathrm{~B}$ isotope ratio. The $\mathrm{B}$ isotope ratio in the tissues over the course of time after ${ }^{10} \mathrm{~B}$ application to one single mature leaf varied significantly $(p<0.01)$ between clones and treatments (Table 2 ). In Bdeficient plants the ${ }^{10} \mathrm{~B}:{ }^{11} \mathrm{~B}$ ratio was reduced in the leaf treated with this nutrient, evidencing translocation out of the source leaf, while the ${ }^{10} \mathrm{~B}:{ }^{11} \mathrm{~B}$ ratio was constant in plants with adequate $B$ supply over the course of time. In young tissues of B-deficient plants the ${ }^{10} \mathrm{~B}:{ }^{11} \mathrm{~B}$ ratio increased for both clones. It was also greater in the mature leaves of clone 129 . The translocation of $\mathrm{B}$ to roots was more limited than the observed to other shoot components.
In the B-deficient plants the foliar application of $\mathrm{H}_{3}{ }^{10} \mathrm{BO}_{3}$ increased the isotope ratio ${ }^{10} \mathrm{~B}:{ }^{11} \mathrm{~B}$ in the treated leaf from around 0.25 to over 2.75 (clone 68 ) and 3.22 (clone 129). In the plants with adequate B supply, however, the ${ }^{10} \mathrm{~B}:{ }^{11} \mathrm{~B}$ ratio was lower - around 0.95 and 0.89 for clones 68 and 129, respectively (Figure 2). The lower ${ }^{10} \mathrm{~B}$ enrichment of plants with adequate $B$ supply shows the dilution of $B$ isotopes since B leaf content (natural abundance) were higher in these plants. From the first day on after application, in B-deficient plants of both clones the ${ }^{10} \mathrm{~B}:{ }^{11} \mathrm{~B}$ ratio was reduced. This shows that the absorbed ${ }^{10} \mathrm{~B}$ was translocated from the source leaf to other plant parts. However, in plants with adequate $\mathrm{B}$ supply, the ${ }^{10} \mathrm{~B}:{ }^{11} \mathrm{~B}$ ratio remained constant over time, providing no evidence of $\mathrm{B}$ translocation (Figure 2).

By the $10^{\text {th }}$ day after ${ }^{10} \mathrm{~B}$ application to the mature leaf ${ }^{10} \mathrm{~B}$ enrichment was observed in the young tissues of the deficient eucalypt plants. The ${ }^{10} \mathrm{~B}:{ }^{11} \mathrm{~B}$ isotope ratio in these tissues was higher in clone 129 than clone 68 (Figure 3). These results are in agreement with those observed for the source leaf (Figure 2). The ${ }^{10} \mathrm{~B}:{ }^{11} \mathrm{~B}$ ratio in the young tissues increased substantially soon after the first day and increased constantly until the time of last sampling (Figure 3). It was verified for cotton (Xie et al., 1992) and for Arabidopsis thaliana (Takano et al., 2001) that B is

Table 2. Boron isotope ratio in eucalypt plant tissue, considering the time of application of ${ }^{10} \mathrm{~B}$ to a mature leaf of B-deficient (-B) or adequately supplied plants (+B)

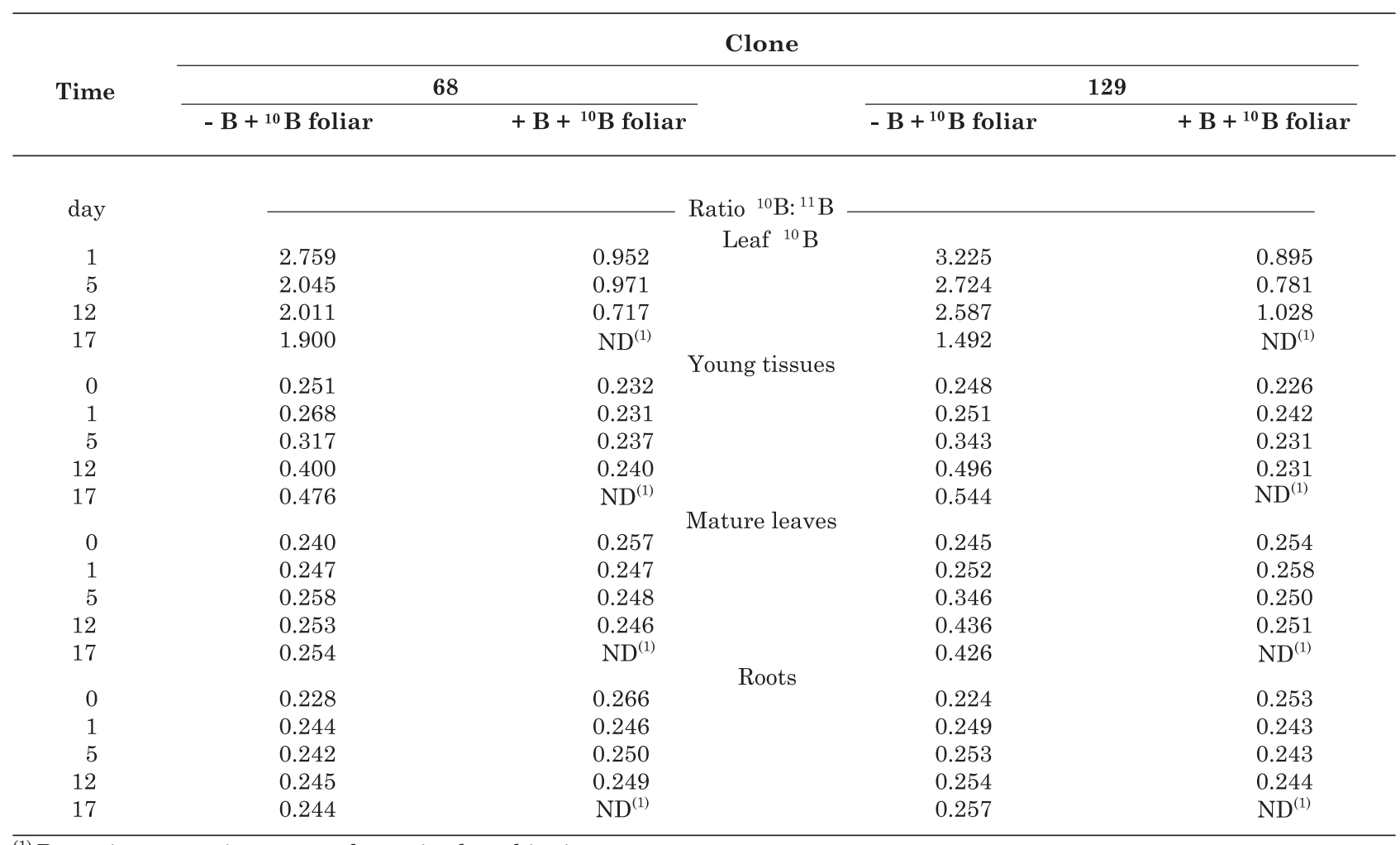

(1) Boron isotope ratio was not determined at this time. 


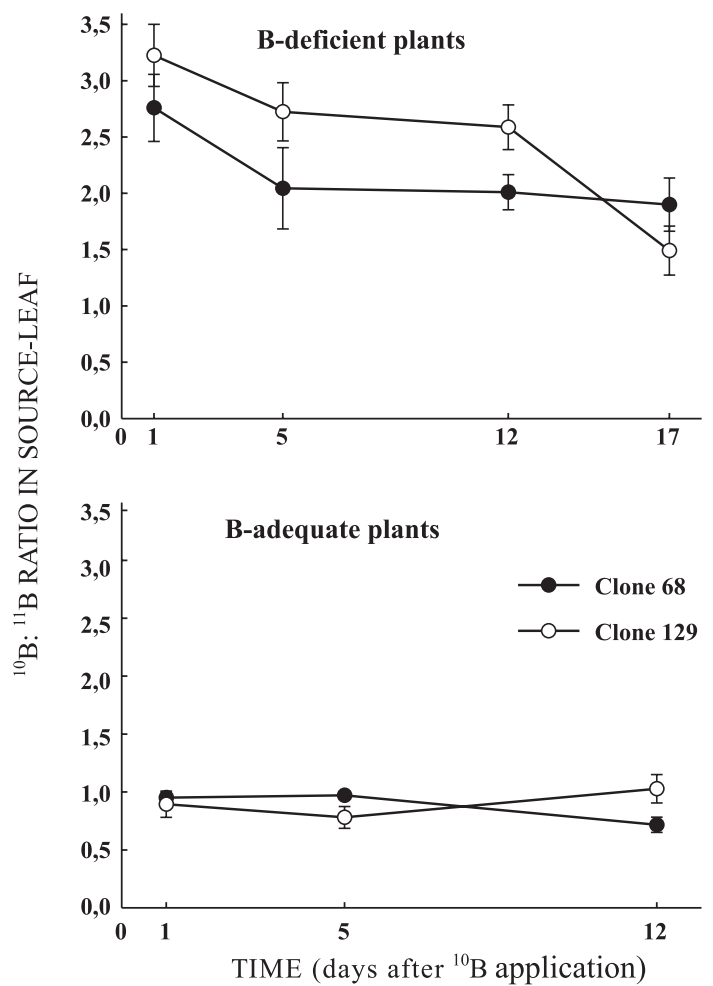

Figure 2. Isotope ratio of ${ }^{10} \mathrm{~B}:{ }^{11} \mathrm{~B}$ over the course of time in a mature leaf treated with application of $\mathrm{H}_{3}{ }^{10} \mathrm{BO}_{3}$ (leaf source) in B-deficient and adequately supplied plants of two eucalypt clones.

preferentially translocated from mature leaves to growing tissues in development, mainly new leaves. In plants with adequate B supply and treated with foliar ${ }^{10} \mathrm{~B}$ no isotope enrichment was observed in young tissues. These results show that B was only translocated from the mature leaf treated with ${ }^{10} \mathrm{~B}$ to young tissues in B-deficient plants. In the mature leaves, pronounced isotope enrichment was only observed in B-deficient plants of clone 129 (Figure 4).

Changes in $\mathrm{B}$ isotope enrichment were observed neither in the mature leaves (Figure 4) nor in the young tissues (Figure 3 ) of plants with adequate $\mathrm{B}$ supply. Shelp et al. (1996) verified that B translocation in broccoli was inversely related with the B status, with higher efficiency in deficient plants. Noguchi et al. (2000), Stangolius et al. (2001) and Matoh \& Ochiai (2005) also stated B translocation under B restriction, unlike under conditions of adequate supply. Our results, together with those of the literature, suggest that $\mathrm{B}$ translocation is an induced mechanism that depends on the plant species as well as the B status.

Boron translocation from the mature leaf treated with $\mathrm{H}_{3}{ }^{10} \mathrm{BO}_{3}$ to the roots of B-deficient 68 and 129 clones was lower than that observed for the shoot (Figure 5). In plants with adequate B supply the ratio was constant over the course of time after the foliar ${ }^{10} \mathrm{~B}$ application. Some authors have suggested that young organs in development, such as leaves and stem apices, are preferential drains for B translocation (Xie et al., 1992; Takano et al., 2001). The isotope ratio results are in agreement with the observed plant symptoms observed-approximately 10 days after the application of ${ }^{10} \mathrm{~B}$ in the mature leaf, intense lateral sprouting was observed near the B treated leaf (Figure 1), whereas little improvement was observed in the root system of B-deficient plants, which remained debilitated by the $\mathrm{B}$ restriction. Besides the limited translocation from the shoot, the lower ${ }^{10} \mathrm{~B}$ enrichment of the clone roots must also be related to the dilution of the ${ }^{10} \mathrm{~B}$ isotopes since in the $\mathrm{B}$ deficient plants $\mathrm{B}$ contents were higher in the roots than in the young and mature leaves.

The relative amount of $\mathrm{B}$ in the young tissues and in mature eucalypt leaves derived from the $\mathrm{H}_{3}{ }^{10} \mathrm{BO}_{3}$ applied once to a single mature leaf varied according to tissue and genetic material as well as the time after application (Figure 6). Seventeen days after ${ }^{10} \mathrm{~B}$ application, B-deficient plants of clone 68 contained approximately $14 \% \mathrm{~B}$ in the young tissues originated from the leaf-applied $\mathrm{H}_{3}{ }^{10} \mathrm{BO}_{3}$, while this percentage was $18 \%$ for clone 129 . In the same period, clone 129 contained $12 \% \mathrm{~B}$ in the mature leaves originated from the leaf-applied $\mathrm{H}_{3}{ }^{10} \mathrm{BO}_{3}$, and clone 68 only $1 \%$.

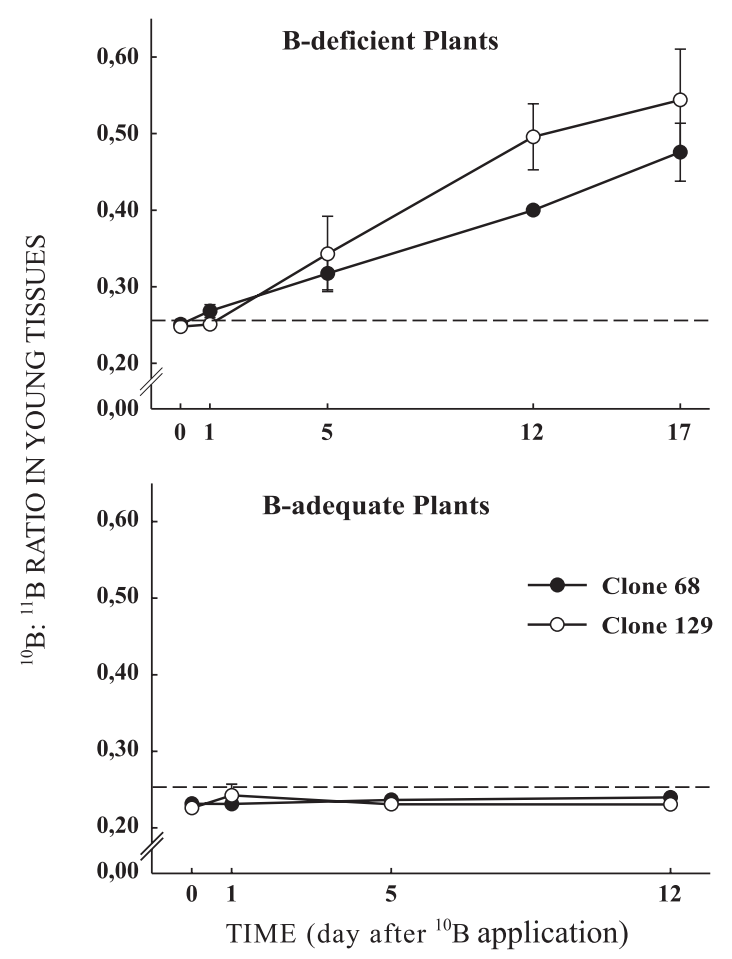

Figure 3. Isotope ratio of ${ }^{10} \mathrm{~B}:{ }^{11} \mathrm{~B}$ in the young tissues over the course of time after application of ${ }^{10} \mathrm{~B}$ to a single mature leaf of B-deficient and adequately supplied plants of two eucalypt clones. The dashed line (---) represents the natural abundance of ${ }^{10} \mathrm{~B}:{ }^{11} \mathrm{~B}=0.247$ of the certified standard NIST SRM-951. 


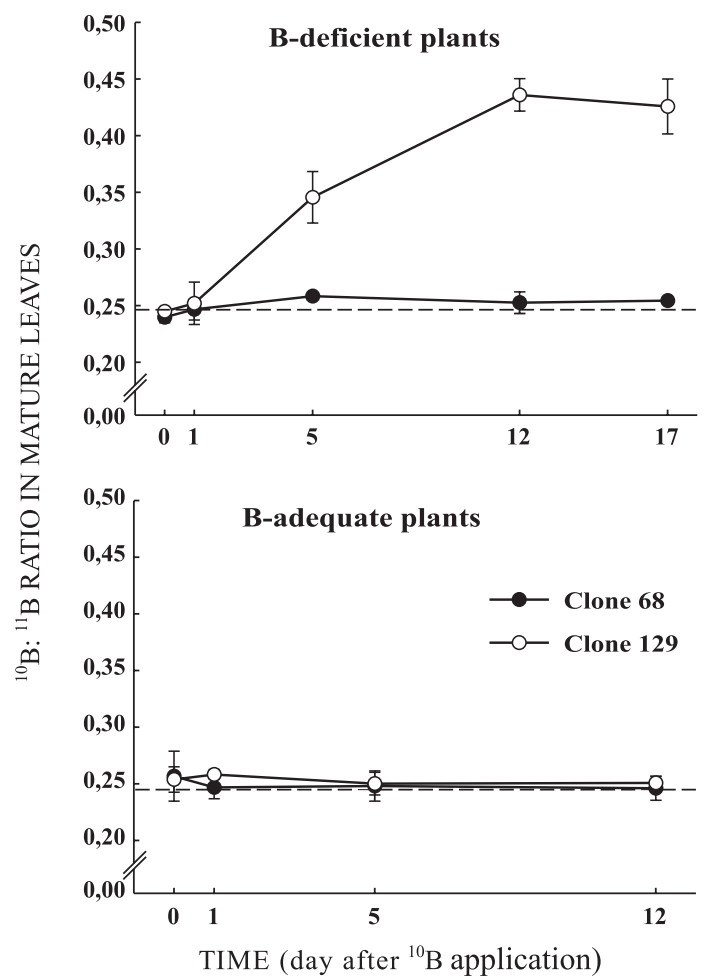

Figure 4. Isotope ratio of ${ }^{10} \mathrm{~B}:{ }^{11} \mathrm{~B}$ in the mature leaves over the course of time after the application of ${ }^{10} B$ to one mature leaf of B-deficient and adequately supplied plants of two eucalypt clones. The dashed line (---) represents the natural abundance of ${ }^{10} \mathrm{~B}:{ }^{11} \mathrm{~B}=0.247$ of the certified standard NIST SRM-951.

Furthermore, less than $0.5 \%$ of the total B in the roots of clone 68 and $1.6 \%$ in the roots of clone 129 were derived from leaf-applied $\mathrm{H}_{3}{ }^{10} \mathrm{BO}_{3}$. The results show the higher efficiency of clone 129 in translocation of leaf-applied B and the importance of the phloem B mobility in growth maintenance of eucalypt plants, especially under conditions of $\mathrm{B}$ deprivation.

Perica et al. (2001b) found that $39 \%$ B present in the inflorescence of olive trees was originated from foliar fertilization. Shelp et al. (1996) verified that inflorescences of broccoli plants under B deficiency, sufficiency and abundance contained, respectively, 25, 10 and $4 \%$ B originated from the foliar application of the nutrient. Leite et al. (2007) reported that $4 \% \mathrm{~B}$ in the fruit and $5 \%$ in the roots of coffee plants were originated from foliar application in B-deficient plants, while in normal plants this percentage was 1.3 and $1.0 \%$, respectively. In orange trees, which are plants known for their restricted B mobility, less than $5 \%$ $\mathrm{B}$ applied to the leaf was translocated to other plant parts, and less than $2.5 \% \mathrm{~B}$ in the young tissues was originated from the fertilizer 270 days after foliar application (Boaretto et al., 2004).

Boron mobility can be variable among species (Brown \& Hu, 1998). Letho et al. (2004) found marked

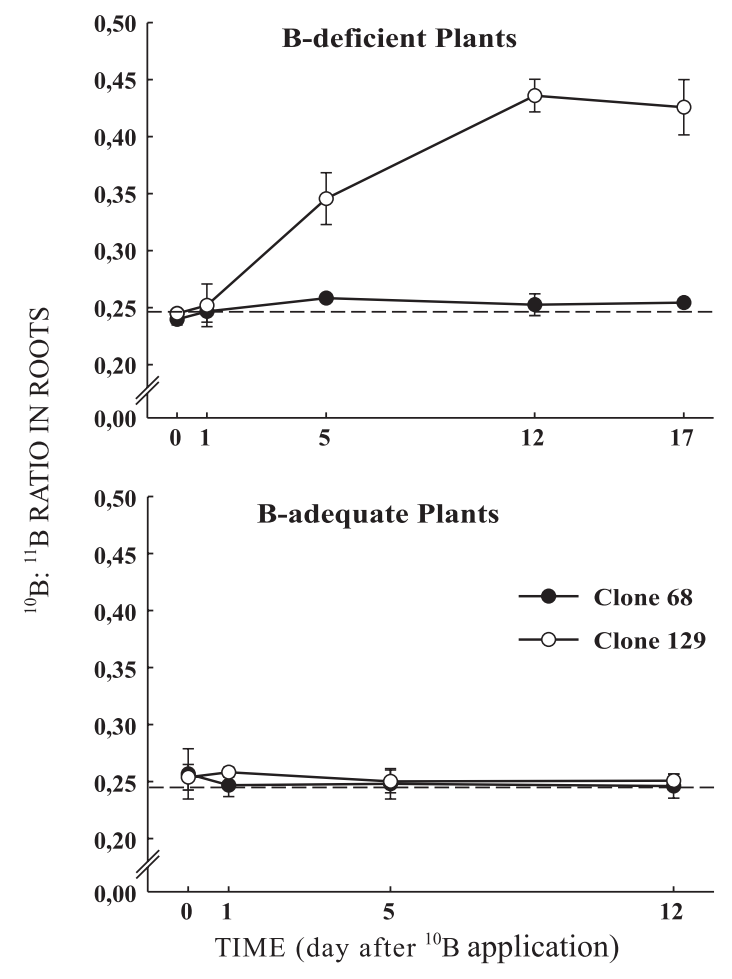

Figure 5. Isotope ratio of ${ }^{10} \mathrm{~B}:{ }^{11} \mathrm{~B}$ in the roots over the course of time after ${ }^{10} \mathrm{~B}$ application to a mature leaf of B-deficient and adequately supplied plants of two deficient eucalypt clones. The dashed line (---) represents the natural abundance of ${ }^{10} \mathrm{~B}:{ }^{11} \mathrm{~B}=0.247$ of the certified standard NIST SRM-951.

differences in B mobility in 12 conifer species, with groups of high, mean and restricted mobility of the nutrient. Boron mobilization in eucalypt clone 129 was more efficient than in clone 68 . A high variability in B mobility is also expected among eucalypt species and clones. This may be an important tolerance mechanism of some genotypes in B-deficient environments and it may reduce the losses caused by $\mathrm{B}$ deficiency under field conditions.

The results for carbohydrate content of plant samples showed high variability. In some cases, high contents and non-detection were observed in the same treatment. The number of replications used (three) was insufficient for a more in-depth analysis of the sugars and polyalcohols. The results presented hereafter should therefore be taken as qualitative and exploratory. The soluble carbohydrates found in eucalypt plants were virtually the same, but their contents varied significantly according to the clone and B treatment (Table 3). The main sugars found in the xylem sap were sucrose, fructose, glucose, galactose and arabinose; sucrose and arabinose contents were highest in clone 129. In the leaves, the sugars fructose, glucose and galactose and the polyalcohol sorbitol prevailed. Clone 68 contained the highest sorbitol and 
clone 129 the highest galactose contents. The contents of the other sugars were similar in both clones. Fructose accumulated in the leaves of B-deficient clones 68 and 129 (Table 3).
Boron mobility in some species has been related to the presence of polyalcohols that form soluble complexes with B, which favor its phloem translocation (Brown \& Hu, 1996, 1998; Brown \& Shelp, 1997; Hu
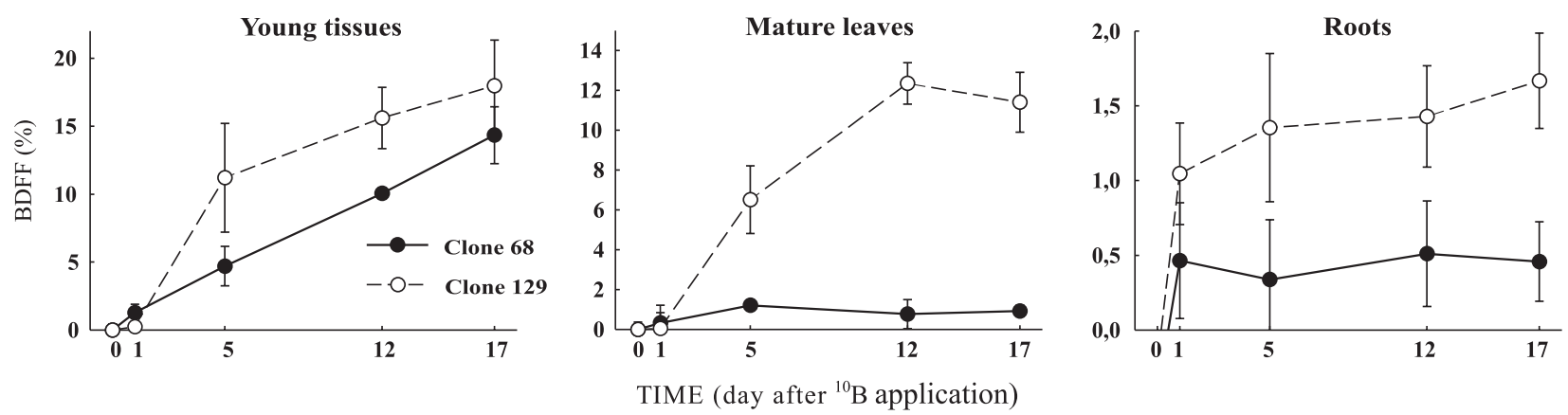

Figure 6. Percentage of B derived from foliar fertilization (BDFF) in the young tissues, mature leaves and roots over the course of time after ${ }^{10} \mathrm{~B}$ application to a mature leaf of eucalypt clones.

Table 3. Soluble carbohydrates in the xylem sap and in eucalypt leaves after ${ }^{10} \mathrm{~B}$ foliar application to Bdeficient (-B) or adequately supplied plants (+B)

\begin{tabular}{|c|c|c|c|c|c|}
\hline \multirow{2}{*}{ Clone } & \multicolumn{3}{|c|}{ Treatment } & \multicolumn{2}{|c|}{ Statistical analysis } \\
\hline & $-\mathbf{B}$ & $-\mathrm{B}+{ }^{10} \mathrm{~B}$ foliar & $+\mathrm{B}+{ }^{10} \mathrm{~B}$ foliar & $\mathbf{L S D}^{(1)}$ & $\operatorname{Means}^{(2)}$ \\
\hline & \multicolumn{5}{|c|}{ Xylem sap } \\
\hline & \multicolumn{5}{|c|}{$\begin{array}{c}\mathrm{mg} \mathrm{L}^{-1} \\
\text { Sucrose }\end{array}$} \\
\hline 68 & 782 & 582 & 796 & 517 & $720 \mathrm{~B}$ \\
\hline \multirow[t]{2}{*}{129} & 1408 & 1435 & 449 & 590 & $1097 \mathrm{~A}$ \\
\hline & & & Fructose & & \\
\hline 68 & 206 & 186 & 192 & 111 & $195 \mathrm{~A}$ \\
\hline \multirow[t]{2}{*}{129} & 237 & 411 & 115 & 308 & $254 \mathrm{~A}$ \\
\hline & & & Glucose & & \\
\hline 68 & 188 & 167 & 175 & 101 & $177 \mathrm{~A}$ \\
\hline \multirow[t]{2}{*}{129} & 246 & 287 & 126 & 153 & $220 \mathrm{~A}$ \\
\hline & & & Galactose & & \\
\hline 68 & 11.23 & 10.92 & 18.63 & 9.23 & $13.59 \mathrm{~A}$ \\
\hline \multirow[t]{2}{*}{129} & 14.81 & 19.26 & 18.19 & 14.58 & $17.42 \mathrm{~A}$ \\
\hline & & & Arabinose & & \\
\hline 68 & 1.64 & 2.49 & 1.76 & 1.22 & $1.96 \mathrm{~B}$ \\
\hline \multirow[t]{3}{*}{129} & 3.45 & 3.61 & 3.09 & 1.90 & $3.38 \mathrm{~A}$ \\
\hline & & & $\begin{array}{l}\text { Leaves } \\
\mathrm{mg} \mathrm{kg}^{-1}\end{array}$ & & \\
\hline & & & Fructose & & \\
\hline 68 & 10.38 & 11.30 & 5.39 & 3.18 & $9.03 \mathrm{~A}$ \\
\hline \multirow[t]{2}{*}{129} & 10.02 & 9.41 & 7.47 & 2.00 & $8.97 \mathrm{~A}$ \\
\hline & & & Glucose & & \\
\hline 68 & 6.59 & 6.59 & 3.77 & 1.77 & $5.65 \mathrm{~A}$ \\
\hline \multirow[t]{2}{*}{129} & 5.64 & 5.26 & 4.78 & 1.180 & $5.23 \mathrm{~A}$ \\
\hline & & & Galactose & & \\
\hline 68 & 0.357 & 0.419 & 0.470 & 0.108 & $0.415 \mathrm{~B}$ \\
\hline \multirow[t]{2}{*}{129} & 0.510 & 0.623 & 0.829 & 0.145 & $0.654 \mathrm{~A}$ \\
\hline & & & Sorbitol & & \\
\hline 68 & 1.051 & 1.116 & 1.088 & 0.438 & $1.085 \mathrm{~A}$ \\
\hline 129 & 0.550 & 0.619 & 0.766 & 0.220 & $0.645 \mathrm{~B}$ \\
\hline
\end{tabular}

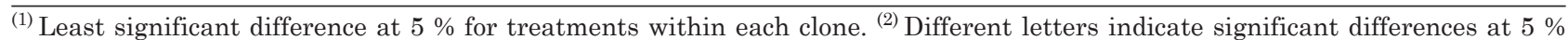
by the $\mathrm{F}$ test. 
et al., 1997; Bellaloui et al., 2003). However, in other species with phloem B mobility, it was not possible to establish a relation between $\mathrm{B}$ translocation and the type or content of polyalcohols. Letho et al. (2004) found lower sorbitol and dulcitol contents at Btranslocating conifers such as Ulmus glabra and Betula pubescens than in Alnus glutinosa, a species with restricted $B$ mobility. In canola, a species with B mobility, the presence of polyalcohols is insignificant (Stangoulis et al., 2001). In the present study, the presence of sorbitol in eucalypt leaves might be related with the observed B mobility. However, the lower content in clone 129 , in which B is more mobile than in clone 68, indicates that other B-complexing organic compounds may be involved in B translocation. Indeed, more detailed studies are necessary to provide further pieces of evidence on the mechanism of $B$ translocation in eucalypt. Different mechanisms may be involved in B plant mobility; moreover, other soluble complexes with B can be biologically important (Brown et al., 2002), such as B-fructose (Hu et al., 1997) and B-malic acid (Dembitsky et al., 2002).

\section{CONCLUSIONS}

1. ${ }^{10} \mathrm{~B}$ applied once only to a single mature leaf was translocated to young tissues and other mature leaves, and in minor quantities to eucalypt roots.

2. B translocation is greater in B-deficient plants.

3. Boron mobility was different among two eucalypt clones.

\section{LITERATURE CITED}

BELLALOUI, N.; YADAVC, R.C.; MAW-SHENG, C.; HU, H.; GILLEN, A.M.; GREVE, C.; DANDEKAR, A.M.; RONALD, P.C. \& BROWN, P.H. Transgenically enhanced sorbitol synthesis facilitates phloem-boron mobility in rice. Physiol. Plant., 117:79-84, 2003.

BOARETTO, A.E.; BOARETTO, R.M.; CONTIN, T.L.M. \& MURAOKA, T. É móvel ou imóvel o boro em laranjeira? Laranja, 25:195-208, 2004.

BROWN, P.H.; BELLALOUI, N.; WIMMER, M.A.; BASSIL, E.S.; RUIZ, J.; HU, H.; PFEFFER, H.; DANNEL, F. \& ROMHELD, V. Boron in plant biology. Plant Biol., 4:203$223,2002$.

BROWN, P.H. \& HU, H. Phloem mobility of boron is species dependent: Evidence for phloem mobility in sorbitol-rich species. Ann. Bot., 77:497-505, 1996.

BROWN, P.H. \& HU, H. Phloem boron mobility in diverse plant species. Bot. Acta, 111:331-335, 1998.

BROWN, P.H. \& SHELP, B.J. Boron mobility in plants. Plant Soil, 193:85-101, 1997.
CLARK, R.B. Characterization of phosphate of intact maize roots. J. Agric. Food Chem., 23:458-460, 1975.

DELGADO, A.; BENLLOCH, M. \& FERNÂNDEZ-ESCOBAR, R. Mobilization of boron in olive trees during flowering and fruit development. Hortic. Sci., 29:616-618, 1994.

DELL, B. \& HUANG, L. Physiological responses of plants to low boron. Plant Soil, 193:85-101, 1997.

DEMBITSKY, V.M.; SMOUM, R.; AL-QUNTAR, A.A.; ALI, H.A.; PERGAMENT, I. \& SREBNIK, M. Natural occurrence of boron-containing compounds in plants, algae and microorganisms. Plant Sci., 163:931-942, 2002.

GUPTA, U.C. Factors affecting boron uptake by plants. In: GUPTA, U.C., ed. Boron and its role in crop production. Boca Raton, 1993. p.87-123.

GUPTA, U.C. Boron and its role in crop production. Boca Raton, CRC Press, 1993b. 237p.

HU, H. \& BROWN, P.H. Localization of boron in cell walls of squash and tobacco and its association with pectin. Plant Physiol., 105:681-689, 1994.

HU, H.; PENN, S.G.; LEBRILLA, C.B. \& BROWN, P.H. Isolation and characterization of soluble B-complexes in higher plants. The mechanism of phloem mobility of boron. Plant Physiol., 113:649-655, 1997.

KONSAENG, S.; DELL, B. \& KERKASEM, B. A survey of wood tropical species for boron retranslocation. Plant Produc. Sci., 8:338-341, 2005.

LEHTO, T.; KALLIO, E. \& APHALO, P.J. Boron mobility in two coniferous species. Ann. Bot., 86:547-550, 2000.

LEHTO, T.; RÄISÄNEN, M.; LAVOLA, A.; JULKUNENTIITTO, R. \& APHALO, P.J. Boron mobility in deciduous forest trees in relation to their polyols. New Phytol., 63:333-339, 2004.

LEITE, V.M.; BROWN, P.H. \& ROSOLEM, C.A. Boron translocation in coffee trees. Plant Soil, 290:221-229, 2007.

MATOH, T. \& OCHIAI, K. Distribution and partitioning of newly take-up boron in sunflower. Plant Soil, 278:351$360,2005$.

NOGUCHI, K.; DANNEL, F.; PFEFFER, H.; ROMHELD, V.; HAYASHI, H. \& FUJIWARA, T. Defect in root-shoot translocation of boron in Arabidopsis thaliana mutant bor1-1. J. Plant Physiol., 156:751-755, 2000.

OERTLI, J.J. \& RICHARDSON, W.F. The mechanism of boron immobility in plants. Physiol. Plant., 23:108-116, 1970.

PERICA, S.; BROWN, P.H.; CONNELL, J.H.; NYOMORA, A.M.S.; DORDAS, C. \& HU, H. Foliar boron application improves flower fertility and fruit set of olive. Hortic. Sci., 36:714-716, 2001b.

PICCHIONI, G.A.; WEINBAUM, S.A. \& BROWN, P.H. Retention and the kinetics of uptake and export of foliageapplied, labeled boron by apple, pear, prune, and sweet cherry leaves. J. Am. Soc. Hortic. Sci., 120:28-35, 1995.

RAVEN, J.A. Short- and long-distance transport of boric acid in plants. New Phytol., 84:231-249, 1980. 
RERKASEM, B. \& JAMJOD, S. Genotypic variation in plant response to low boron and implications for plant breeding. Plant Soil, 193:169-180, 1997.

SGARBI, F.; SILVEIRA, R.L.V.A.; TAKAHASHI, E.N. \& CAMARGO, M.A.F. Crescimento e produção de biomassa de clone de Eucalyptus grandis x Eucalyptus urophylla em condições de deficiência de macronutrientes, B e Zn. Sci. Flor., 56:69-83, 1999.

SHELP, B.J.; MARENTES, E.; KITHEKA, A.M. \& VIVEKANANDAN, P. Boron mobility in plants. Physiol. Plant., 94:356-361, 1995.

SHELP, B.J.; VIVEKANANDAN, P.; VANDERPOOL, R.A. \& KITHEKA, A.M. Translocation and effectiveness of foliarapplied boron in broccoli plants of varying boron status. Plant Soil, 183:309-313, 1996.
STANGOLIUS, J.C.; BROWN, P.H.; BELLALOUI, N.; REID, R.J. \& GRAHAM, R.D. The efficiency of boron utilisation in canola. Aust. J. Plant Physiol., 28:1109-1114, 2001.

TAKANO, J.; YAMAGAMI, M.; NOGUCHI, K.; HAYASHI, H. \& FUJIWARA, T. Preferential translocation of boron to young leaves in Arabidopsis thaliana regulated by the BOR1 gene. Soil Sci. Plant Nutr., 47:345-357, 2001.

WANG, G.; ROMHELD, V.; LI, C. \& BANGERTH, F. Involvement of auxin and CKs in boron deficiency induced changes in apical dominance of pea plants (Pisum sativum L.). J. Plant Physiol., 163:591-600, 2006.

XIE, Q.; WEI, W.X. \& WANG, Y.H. Studies on absorption, translocation and distribution of boron in cotton (Gossypium hirsutum L.). Acta Agron. Cínica, 18:31-37, 1992. 